\author{
Oleksandr Polishchuk, \\ PhD (Candidate of Philological Sciences), senior lecturer, \\ National University of Life and Environmental Sciences of Ukraine, \\ 15, Heroiv Oborony Str., Kyiv, Ukraine
}

\title{
COMMUNICATION BARRIERS FACED BY ENGLISH LANGUAGE LEARNERS AT A UNIVERSITY LEVEL: FACTORS AND SOLUTIONS
}

\begin{abstract}
Many graduates of Ukrainian higher educational institutions cannot interact with others in English because of numerous barriers to effective communication. The present study aims 1) to investigate the barriers to effective foreign language communication among the university students and 2) to find out some effective solutions to the problem so that both teachers and students could benefit in their objectives and outcomes regarding communication skills. The research outcomes have shown that Ukrainian university students face different issues in communication proficiency though they generally have positive attitude towards learning English. It has been found out that the participants of this study face language (vocabulary and grammar) barriers, psychological barriers (fear of making mistakes, fear of speaking in front of the class), lack of contact hours, inappropriate teaching methods, curricula and textbooks as factors that lead to the failure to effectively communicate in English. Another major factor is that many university students get confused when native speakers use different slang words, proper names, local names, food names, etc. and speak very quickly and may have different accents. The present study also attempted to highlight some strategies for coping with communication barriers such as use of appropriate teaching methods and aids, avoiding frequent error correction, practicing communication skills outside the classroom, exploiting collaborative work and authentic materials, making students aware of cultural diversity and differences as well.
\end{abstract}

Keywords: English as a Foreign Language, communication, communication barriers, coping strategies.

\section{Introduction}

Globalization and expansion of English in the world have changed the English language teaching and learning scenario: teaching nowadays is not just improving reading or writing skills and training students for examinations, but also increasing their employment potential by strengthening their communication skills. Unfortunately, many graduates of Ukrainian higher educational institutions cannot interact with others in English because of numerous barriers to effective communication. Communication is considered to be "the activity of conveying information through the exchange of ideas, feelings, intentions, expectations, perceptions or commands by speech, writing, gestures and by other means between two or more participants" [1]. This process requires a source/sender who encodes information in the form of a message which is transmitted through a medium/channel to a recipient who then decodes the message and gives necessary response/feedback. Effective communication occurs when it serves the purpose for which it was planned, however, when the desired effect is not achieved, barriers which act as obstacles to effective communication need to be explained. As Nilanjana Pal et al mention, these include "filtering, selective perceptions, information overload, emotions, language, silence, communication apprehension or anxiety, gender difference and many other factors" [4, p. 104]. These barriers to effective communication can distort the message at any stage in the communication process. Considering the reasons that create communication barriers, Norrish identified a number of factors that include lack of motivation, first language interference, literal translation from the first language into the target one, overgeneralization of grammar rules, material-induced errors, lack of command of the target, interlanguage errors as well [5, p. 21-39].

Due to inappropriate curricula and teaching methodologies, non-supportive environment, lack of motivation and other reasons, English as a Foreign Language (EFL) learners at Ukrainian higher educational institutions do not possess the required proficiency and communicative skills. Thus, the present study aims 1) to investigate the barriers to effective EFL communication among the university students and 2) to find out some effective solutions to the problem so that both teachers and students could benefit in their objectives and outcomes regarding EFL communication skills.

\section{Research methods}

In this paper we use both theoretical and empirical methods of study. We apply literature review method to analyze and interpret the available literature related to the topic and obtain the actual information about the barriers to EFL communication. The carried out experiment involved first year EFL students selected from various university faculties: faculty of Agricultural Management (group 1), Agrobiological faculty (group 2), Mechanical and Technological faculty (group 3), faculty of Design and Engineering (group 4) of the National University of Life and Environmental Sciences of Ukraine, Kyiv. A total of 124 students (76 boys and 48 girls) aged 18-20 were selected basically through the purposive sampling method on the basis of convenience and availability and suggested to fill in a questionnaire. 


\section{Research Results and their Discussion}

It has been reported that "because of insufficient authentic resources and the need to use the target language, EFL learners generally encounter difficulties developing communicative competence" [2, p.165]. The European Reference Framework of Key Competences for Lifelong Learning defines communication in foreign languages as the competence that broadly shares the main skill dimensions of communication in the mother tongue: "it is based on the ability to understand, express and interpret concepts, thoughts, feelings, facts and opinions in both oral and written forms (listening, speaking, reading and writing) in an appropriate range of societal and cultural contexts (in education and training, work, home and leisure) according to one's desires or needs" $[7,5]$. In real-life communication, we use a language to express what we mean; however, a language is more than a tool for communication, it also represents social and cultural background. By acquiring target language knowledge, EFL learners cannot be successfully engaged into real-life communication in the target culture; they also need to acquire pragmatic competence, the capacity to incorporate cultural knowledge into language use and choose appropriate language in different sociocultural contexts. Thus, communication in foreign languages implies the elements of linguistic, communication and intercultural competence. One of the most significant changes in recent years has been the recognition of the cultural dimension as a key component of language studies. Therefore, present day foreign language teaching is a complex process in terms of its content, aims and competence development.

The need to communicate occurs in a particular situation which shapes the form and content of that particular communication. Nazari believes that social and cultural aspects are already within the language, thus language teaching and learning should not be separated from the target community's social practice context, and otherwise language learning process is deemed to be useless [3]. Effective communication skills not only help students to improve their academic performance but increase their employment options, enhance their subsequent professional competence, and improve their personal effectiveness. However, while communicating in English, the learners encounter varied problems that evidently handicap and hamper their communication and negatively affect their general proficiency.

Such barriers to communication may include:

- language barriers to communication (the inability to communicate using a language);

- cultural barriers to communication (the way people think and behave in different cultures);
- physical barriers to communication (environmental and natural conditions that act as a barrier in communication in sending and receiving messages);

- physiological barriers to communication (psychological factors such as misperception, stress, filtering, distrust, worries, and people's state of mind can effect communication with others);

- social barriers to communication (include a social psychological phenomenon of conformity, a process in which the norms, values, and behaviors of an individual begin to follow those of the wider group. Social factors such as age, gender, socioeconomic or marital status may act as a barrier to communication in certain situations);

- semantic barriers to communication (symbolic obstacles that distort the sent message in some other way than intended, making the message difficult to understand; language, jargon, slang, etc., are some of the semantic barriers)

The main focus of our study is language, psychological and sociocultural barriers to communication experienced by EFL learners at university level.

Language (semantic barriers).

Language is the main medium of communication and words are its tools. The words we select, the way we use them, and the meaning we attach to them may cause many communication barriers as well as barriers at semantic, syntactic, phonological and linguistic levels.

Psychological barriers arise in the human mind and not always communication can result in understanding. Psychological factors which may become barriers to a meaningful communication include: emotions (both positive and negative emotions may act as barriers, if they are not kept under control); prejudices (e.g., prejudices about certain communities or groups of people), closed mind (when a person refuses to accept other one's idea or opinion that is different from his/her own one); social or professional status (when a person becomes too conscious of his/her status, whether high or low, then status becomes a barrier); impatience (listening without attention or empathy), etc.

Cultural diversity within a country and cultural differences between people from different countries are a major cause of cultural barriers. This is because people are conditioned by their cultures and they develop certain habits of working, communicating, eating, dressing etc. according to their cultural conditioning.

Based on literature review, a questionnaire was elaborated and administered to 4 groups of students of the National University of Life and Environmental Sciences of Ukraine, Kyiv. Table 1 presents the data related to attitudes and barriers of the university students towards English communication. 
Table 1.

Attitudes and Barriers towards English Communication

\begin{tabular}{|c|c|c|c|c|c|c|}
\hline \# & Attitudes and barriers & $\begin{array}{c}\text { Group } \\
1\end{array}$ & $\begin{array}{c}\text { Group } \\
2\end{array}$ & $\begin{array}{c}\text { Group } \\
3\end{array}$ & $\begin{array}{c}\text { Group } \\
4\end{array}$ & Average \\
\hline 1 & $\begin{array}{l}\text { Speaking English is an important skill at a university } \\
\text { level. }\end{array}$ & $92 \%$ & $87 \%$ & $93 \%$ & $81 \%$ & $88.25 \%$ \\
\hline 2 & Listening and Speaking English is tedious for me. & $74 \%$ & $67 \%$ & $62 \%$ & $79 \%$ & $70.5 \%$ \\
\hline 3 & $\begin{array}{l}\text { I cannot speak English fluently because I translate } \\
\text { utterances from Ukrainian. }\end{array}$ & $85 \%$ & $91 \%$ & $78 \%$ & $88 \%$ & $85.5 \%$ \\
\hline 4 & I enjoy speaking English in the classroom. & $43 \%$ & $52 \%$ & $47 \%$ & $53 \%$ & $48.75 \%$ \\
\hline 5 & $\begin{array}{l}\text { English pronunciation is difficult for speaking and } \\
\text { understanding. }\end{array}$ & $23 \%$ & $31 \%$ & $26 \%$ & $29 \%$ & $27.25 \%$ \\
\hline 6 & English grammar is difficult for me when I speak. & $62 \%$ & $67 \%$ & $59 \%$ & $60 \%$ & $62 \%$ \\
\hline 7 & $\begin{array}{l}\text { Lack of adequate vocabulary makes speaking diffi- } \\
\text { cult for me. }\end{array}$ & $84 \%$ & $78 \%$ & $90 \%$ & $86 \%$ & $84.5 \%$ \\
\hline 8 & $\begin{array}{l}\text { The difference between English and Ukrainian } \\
\text { grammar makes English speaking difficult for me. }\end{array}$ & $61 \%$ & $52 \%$ & $54 \%$ & $62 \%$ & $57.25 \%$ \\
\hline 9 & $\begin{array}{l}\text { I feel embarrassed and nervous when I speak English } \\
\text { in front of the class. }\end{array}$ & $44 \%$ & $45 \%$ & $52 \%$ & $49 \%$ & $47.5 \%$ \\
\hline 10 & $\begin{array}{l}\text { I prefer not to speak in the classroom because I am } \\
\text { afraid of making mistakes. }\end{array}$ & $62 \%$ & $64 \%$ & $60 \%$ & $59 \%$ & $61.25 \%$ \\
\hline 11 & $\begin{array}{l}\text { I prefer not to speak English in the classroom be- } \\
\text { cause my peers will laugh at me. }\end{array}$ & $31 \%$ & $22 \%$ & $27 \%$ & $18 \%$ & $24.5 \%$ \\
\hline 12 & $\begin{array}{l}\text { I am afraid that my English teacher will laugh if I } \\
\text { make a mistake. }\end{array}$ & $42 \%$ & $35 \%$ & $36 \%$ & $27 \%$ & $35 \%$ \\
\hline 13 & $\begin{array}{l}\text { I hate speaking English because of my English lan- } \\
\text { guage teachers (at school or college levels) due to } \\
\text { faulty teaching methods, curricula and textbooks. }\end{array}$ & $82 \%$ & $73 \%$ & $61 \%$ & $63 \%$ & $69.75 \%$ \\
\hline 14 & $\begin{array}{l}\text { English contact hours are not sufficient to have } \\
\text { enough practice of speaking skills. }\end{array}$ & $96 \%$ & $97 \%$ & $94 \%$ & $98 \%$ & $96.25 \%$ \\
\hline 15 & $\begin{array}{l}\text { I prefer to interact with native speakers to improve } \\
\text { my speaking skills. }\end{array}$ & $52 \%$ & $46 \%$ & $48 \%$ & $34 \%$ & $45 \%$ \\
\hline 16 & $\begin{array}{l}\text { I prefer to watch English movies to improve my } \\
\text { speaking skills. }\end{array}$ & $12 \%$ & $17 \%$ & $19 \%$ & $24 \%$ & $18 \%$ \\
\hline 17 & $\begin{array}{l}\text { I can understand my English teacher but I cannot } \\
\text { understand native English speakers. }\end{array}$ & $65 \%$ & $58 \%$ & $54 \%$ & $63 \%$ & $60 \%$ \\
\hline 18 & $\begin{array}{l}\text { I get confused when native speakers use different } \\
\text { slang words, proper names, local names, food } \\
\text { names, etc. }\end{array}$ & $98 \%$ & $86 \%$ & $94 \%$ & $91 \%$ & $92.25 \%$ \\
\hline 19 & $\begin{array}{l}\text { I fail to understand fluent speech and different ac- } \\
\text { cents. }\end{array}$ & $82 \%$ & $75 \%$ & $87 \%$ & $76 \%$ & $80 \%$ \\
\hline 20 & $\begin{array}{l}\text { I fail to communicate effectively with native speak- } \\
\text { ers because I am not sure what is considered 'freely } \\
\text { available' and what is considered a taboo topic. }\end{array}$ & $33 \%$ & $27 \%$ & $42 \%$ & $51 \%$ & $38.25 \%$ \\
\hline
\end{tabular}

The comparative analysis has indicated little differences in the perceptions of all four groups. All the respondents have stated that English communication skills are important at a university level $(88.25 \%)$, though most of them bear weaknesses in speaking and listening proficiency due to miscellaneous factors. These barriers include differences between the English and Ukrainian grammar (57. 25\%), poor vocabulary $(84.5 \%)$ and grammar skills (62\%), translating utterances from Ukrainian in one's mind while speaking (85.5\%), however, English pronunciation does not prevent most of the students from effective speaking and understanding (only $27.25 \%$ of the respondents regard it as a barrier). Other factors include psychological barriers such as fear of making mistakes $(61.25 \%)$ and fear of speaking in front of the class. It should be noted that only one third of the students are scared to be laughed at by their classmates $(24.5 \%)$ and teachers (35\%) for making mistakes. The students' most preferred way of improving speaking skills is interacting with native speakers (45\%) and they do have enough opportunities to interact with natives frequently, whereas watching English movies is preferred only by $18 \%$ students. The findings of our research have also suggested that insufficient English contact hours are a major hindrance in achieving English communication proficiency among the university students $(96.25 \%) .69 .75 \%$ re- 
spondents were not satisfied with their English language teachers (at school or college), their teaching methods, curricula and textbooks, that is why $60 \%$ students were able to understand their English teacher but found it difficult to understand native speakers. Another important finding is that a great number of participants got confused when native speakers used different slang words, proper names, local names, food names, etc. (92.25\%), spoke too fluently or used different accents (80\%). However, such cultural issues as what is considered "freely available" and what is considered a taboo topic, were not a big barrier to effective communication with natives for $38.25 \%$ respondents.

Based on the findings of our research, it has been suggested that English teachers need to pay greater attention while planning their English lessons and they should realize that teaching real communication is not merely teaching English pronunciation, vocabulary and grammar. According to Nilanjana Pal et al, "there are many intervening variables lying between the source and the receiver of communication. A communicator must be aware of the nature and effect of these intervening variable - if properly employed the same elements that are barriers to communication become facilitators" [4, p. 115]. It also seems inevitable that English language teachers should take additional measures to provide their students with the chances to improve speaking proficiency. In order to encourage students in exerting their optimum efforts to improve their speaking skills, the faculty members should make them realize that communication proficiency cannot be achieved without intensive practice of the target language in various contexts; Ukrainian EFL learners should be convinced to use the target language not only in the academic setting but also they should be motivated to practice it as much as possible outside the classroom. Joining online special interest groups may be instrumental to maximize the chances to practice English more frequently. It seems very important that teachers should exploit positive attitudes of students towards speaking English and try their level best to keep their motivation high. English language teachers should ensure variety and innovation in speaking skills activities to avoid monotony and boredom and provide the speaking process with favorable environment by exploiting collaborative work and authentic materials, by increasing time for talking, providing encouragement of students, avoiding frequent correction of errors that may distract learners and making students aware of cultural diversity and differences. The use of appropriate teaching aids such as language laboratories,

\section{REFERENCES}

1. Chigicherla, Thirupal Reddy (2014). Communication and its types. International Research Journal of Management Sociology \& Humanities, Vol.5 [in English].

2. Larsari, V.N. (2011). Learners' communicative competence in English as a foreign language (EFL). Journal of English and literature, Vol. 2(7), pp. 161-165 [in English]. audio-visual aids, computers and power point presentations should be appropriately used to keep the interest level high.

Other tips on how to overcome EFL barriers may be as follows:

- creating low-anxiety environment (a setting where students feel safe to take risks and feel supported by their teacher and peers without the fear of being laughed at or made fun of);

- repeated practice (students need multiple opportunities to comprehend and express their ideas in a new language);

- using comprehensible input (finding different ways to make what is being said comprehensible and easier to understand);

- using drama (such activities as role-playing, puppetry, narrating wordless picture books, etc. All of these activities assist in the development of communication skills in addition to introducing students to rich literacy experiences and responses in a classroom setting);

- creating grouping structures that set students up for success (teachers can improve engagement and motivation by creating choice/interest groups where students gather, read, discuss the common topics and work together).

\section{Conclusion}

The findings of this empirical study reveal that Ukrainian university students face different issues in communication proficiency though they generally have positive attitude towards learning English and they strongly agree that it is significant for their studies at university and communication is an extremely important life skill. It has been found out that the participants of this study face language (vocabulary and grammar) barriers, psychological barriers (fear of making mistakes, fear of speaking in front of the class), lack of contact hours, inappropriate teaching methods, curricula and textbooks as factors that lead to the failure to effectively communicate in English. Another major factor is that many university students get confused when natives use different slang words, proper names, local names, food names, etc. and speak too fluently and may have different accents. The present study also attempted to highlight some strategies for coping with communication barriers such as use of appropriate teaching methods and aids, avoiding frequent error correction, practicing communication skills outside the classroom, exploiting collaborative work and authentic materials, making students aware of cultural diversity and differences as well.

3. Nazari, A. (2007). EFL Teachers' Perception of the Concept of Communicative Competence. ELT Journal, 61/3, p. 202-210 [in English].

4. Pal, Nilanjana, Halder, Santoshi, Guha, Abhijit. (2006). Study on Communication Barriers in the Classroom: A Teacher's Perspective. Online Journal of Communication and Media Technologies, Vol.6, Issue 1 [in English]. 
5. Norrish, J. (1983). Language Learners and their Errors. London: Macmillan Press London [in English].

6. Seidlhofer, B. (2005). English language as a lingua franca. ELT Journal, 59 (4), 339-341 [in English].

7. The Key Competences for Lifelong Learning - A European Framework. Recommendation of the European

\section{ЛІТЕРАТУРА}

1. Chigicherla T. R. Communication and its types / Thirupal Reddy Chigicherla // International Research Journal of Management Sociology \& Humanities. 2014. - Vol.5.

2. Larsari V.N. Learners' communicative competence in English as a foreign language (EFL) / V.N. Larsari //Journal of English and literature /-2011.-Vol. 2(7). - P. 161-165.

3. Nazari A. EFL Teachers' Perception of the Concept of Communicative Competence / A. Nazari //ELT Journal. - 2007. - No. 61/3. - P. 202-210.

4. Nilanjana P. Study on Communication Barriers in the Classroom: A Teacher's Perspective / P. Nilanjana, H. Santoshi, G. Abhijit // Online Journal of Communication and Media Technologies. - 2006. -Vol.6, Issue 1.
Parliament and of the Council. Belgium: European Communities, 18 December 2007. Available: http://ec.europa.eu/dgs/education_culture/publ/pdf/lllearni ng/keycomp_en.pd [in English].

5. Norrish J. Language Learners and their Errors / J. Norrish. - London: Macmillan Press London, 1983.

6. Seidlhofer B. English language as a lingua franca / B. Seidlhofer // ELT Journal. - 2005. - No. 59 (4). - P. 339-341.

7. The Key Competences for Lifelong Learning. A European Framework. Recommendation of the European Parliament and of the Council. [Електронний ресурс] / The Key Competences for Lifelong Learning // Belgium: European Communities. - 2007

Режим доступу до ресурсу:

http://ec.europa.eu/dgs/education_culture/publ/pdf/lllearni ng/keycomp_en.pd.

\section{Олександр Сергійович Полішук, кандидат філологічних наук, старший викладач, Національний університет біоресурсів і природокористування України, вулиия Героїв Оборони, 15, Київ, Украӥна}

\section{КОМУНІКАТИВНІ БАР'ЄРИ, ЩО ПОСТАЮТЬ ПЕРЕД СТУДЕНТАМИ ПРИ ВИВЧЕННІ АНГЛІЙСЬКОЇ МОВИ НА РІВНІ УНІВЕРСИТЕТУ: ФАКТОРИ ТА РІШЕННЯ}

Глобалізація та експансія англійської мови у світі змінили сценарій викладання англійської мови та ії вивчення: сьогодні іншомовна освіта - це не просто покращення навичок читання та письма, а також підготовка студентів до іспитів, але й формування їхньої іншомовної професійної компетенції, конкурентноспроможності шляхом зміцнення комунікативних навичок. На жаль, багато випускників українських вищих навчальних закладів не можуть ефективно взаємодіяти з іншими англійською мовою через численні перешкоди для ефективного спілкування. Таким чином, наше дослідження спрямоване на 1) вивчення бар'єрів ефективного спілкування англійською мовою, які відчувають студенти українських вишів, та 2) пошук ефективних рішень проблеми для формування стійких іншомовних комунікативних навичок. Результати проведеного дослідження демонструють, що студенти зіштовхуються з різними проблемами спілкування, хоча в цілому вони позитивно ставляться до вивчення англійської мови. Виявлено, що учасники експерименту зіштовхуються 3 мовним бар'єром (лексика та граматика), психологічним бар'єром (страх помилитися, страх виступати перед аудиторією), а також такими проблемами як-от: мала кількість мовних занять на тиждень, невідповідні методи навчання, застарілі навчальні плани та підручники як фактори, що призводять до неспроможності ефективно спілкуватися англійською мовою. Інший важливий чинник полягає в тому, що багато студентів університету почуваються невпевнено, коли носії мови використовують різні сленгові слова, власні назви, місцеві назви, назви продуктів, розмовляють у швидкому темпі, з різними акцентами тощо. У нашому дослідженні ми також намагалися висвітлити деякі стратегії подолання бар'єрів англомовної комунікації, такі, як використання адекватних методів навчання та допоміжних засобів, запобігання частому виправленню помилок, формування навичок спілкування поза межами аудиторії, використання кооперативних методів навчання та автентичних матеріалів, формування знань про культурні відмінності та розмаїття культур у світі.

Ключові слова: англійська мова як іноземна мова, спілкування, бар'єри спілкування, стратегії подолання.

Reviewed by Doctor of Pedagogy, prof. O. Bezkorovaina

Submitted on June, 7, 2017 